University of Nebraska - Lincoln

DigitalCommons@University of Nebraska - Lincoln

Faculty Publications: Department of Entomology

7-1968

\title{
The Biology of Choristoneura houstonana (Lepidoptera: Tortricidae), a Pest of Juniperus Species
}

\author{
E. A. Heinrichs
}

Hugh E. Thompson

Follow this and additional works at: https://digitalcommons.unl.edu/entomologyfacpub

Part of the Entomology Commons, and the Forest Biology Commons

This Article is brought to you for free and open access by the Entomology, Department of at

DigitalCommons@University of Nebraska - Lincoln. It has been accepted for inclusion in Faculty Publications:

Department of Entomology by an authorized administrator of DigitalCommons@University of Nebraska - Lincoln. 
Published in The Canadian Entomologist 100:7 (July 1968), pp. 750-763; doi: 10.4039/Ent100750-7

Copyright (C) 1968 Entomological Society of Canada; published by Cambridge University Press. Used by permission.

Submitted January 31, 1968; published online May 31, 2012.

\title{
The Biology of Choristoneura houstonana (Lepidoptera: Tortricidae), a Pest of Juniperus Species ${ }^{1}$
}

\author{
E. A. Heinrichs and Hugh E. Thompson
}

Department of Entomology, Kansas State University, Manhattan, Kansas, USA

\begin{abstract}
Choristoneura houstonana (Grote) lays eggs singly in July. Egg development ranged from 8 to 11 days, with the majority hatching 10 days after oviposition.

Larvae are solitary, and mine during early instars, but later instars feed externally on leaves in shelters made by webbing foliage together. There is one generation each year, and overwintering occurs in a hibernaculum, in mined leaves. Field-collected head-capsule width frequencies indicated nine larval instars. Rearing larvae on seedling junipers indoors indicated a range of 8-11 instars.

Pupation occurs during June and July in the shelter where the larva feeds. The pupal stage lasted about 10 days at a constant temperature of $80^{\circ} \mathrm{F}$.

\section{Introduction}

The first reliable record of Choristoneura houstonana (Grote) in Kansas was made in 1964 from a sample of Juniperus virginiana (L.) containing larvae received from Rooks County by the Department of Entomology at Kansas State University. Larvae were reared to adulthood. The adults were identified by R. W. Hodges, United States Department of Agriculture, Agricultural Research Service, Entomology Division, Insect Identification and Parasite Introduction Section, as Choristoneura houstonana (Grote). It may have been in Kansas many years, as the United States National Museum (Hodges, personal communication) lists this reference concerning C. houstonana: 1 female (Kansas ?) on cedar, 21 June 1889.
\end{abstract}


Choristoneura houstonana is not considered an economic pest by the U.S. Plant Pest Control Division (Dorward, personal communication, 1964). However, C. houstonana has been collected mostly in areas of the United States where Juniperus spp., the host plants, are of no value. It is of economic importance in western Kansas where heavy infestations of $C$. houstonana damage windbreak and ornamental trees.

The type specimen, Tortrix houstonana, collected in Texas from "cedar," was described by Grote (1873). Both Freeman (1958) and Powell (1964), in taxonomic studies of Tortricidae, placed houstonana in the genus Choristoneura. However, doubt has been expressed that it belongs in the genus Choristoneura because the female genitalia differ considerably from other members of the genus. Powell (personal communication, 1965) states that $C$. houstonana females are equipped with a very peculiar arrangement of the papillae anales as the external ovipositor is "blade-like" as in many species of Ethmia and certain olethreutids. To Powell's knowledge, no other archipine species has that development.

Powell (1964) states that $C$. houstonana is distributed throughout the pinyon-juniper woodland areas of the southwestern states and the Great Basin. A single record from Barnstable, Massachusetts, indicates lack of knowledge of its distribution in eastern United States.

Powell (1962) has recorded information on the parasites of C. houstonana in California and Heinrichs and Thompson (1968) have recorded information on predators and parasites in Kansas. Powell ( 1964) discusses the host plants and habits of C. houstonana in California. Heinrichs (1967) studied the distribution of C. houstonana on the host plant J. virginiana (eastern redcedar) in Kansas.

\section{Materials and Methods}

Observations on natural infestations of $C$. houstonana were made at 15 locations in nine Kansas counties, Smith, Phillips, Ellis, Rooks, Pawnee, Barton, Edwards, Pratt, and Barber. The Larned Country Club in Pawnee County was chosen as the principal study site with approximately 200 naturally infested junipers. Additional trees were planted in one large cage at the Kansas State University Ashland Experiment Farm, a few miles from Manhattan, and artificially infested with last-instar larvae. Observations were made also on juniper seedlings grown and artificially infested in a greenhouse or growth chamber.

Oviposition studies were conducted by placing laboratory-reared and field-collected adults in plastic jelly cups ${ }^{2}$ held in a rearing room at $80^{\circ} \mathrm{F}$ and $70 \%$ relative humidity. Small holes punctured in the caps allowed air to enter; the cup was inverted, cap down. Most of the eggs were laid on the plastic liner of the cap. Caps were replaced daily and the eggs counted.

To study rate of embryo development, eggs were kept in plastic jelly cups in a rearing room at $80^{\circ} \mathrm{F}$ and $70 \%$ relative humidity. Number of visible embryo head capsules and number of eggs hatched each day after oviposition were recorded. Emerged larvae were removed from the cups daily.

Two methods were used to determine the number of larval instars: (1) measurement of head-capsule widths of weekly, field-collected larvae; and (2) rearing of larvae on small junipers in a growth chamber or greenhouse. 
Infested foliage was collected approximately each week from 15 July 1965 to 15 July 1966. Larvae were removed from the foliage, killed in ethanol, and about 50 larval head capsules were measured at the widest point. In addition to those weekly collections, many overwintering and late-instar larvae were collected and measured during the winter and spring of 19641965. The combined data were used to construct a head-capsule width frequency histogram with larval frequency on the ordinate and head width on the abscissa. It was assumed each peak on the histogram indicated an instar.

Infested trees were grown in a growth chamber at $80^{\circ} \mathrm{F}$, approximately $45 \%$ relative humidity, and a 17-hour photoperiod or in a greenhouse with fluctuating temperatures and humidity. A plastic box 2 7/8 in. $\times 13 / 16$ in. $\times 1$ in., with small nylon-screen-covered air holes, was placed around the area of foliage after each larva had established itself as indicated by webbing. A branch was cut from the tree after the larva completed its development, pupated, and emerged as an adult. Head capsules were removed from among the webbing and fecal pellets in the boxes counted and measured.

Feeding behavior of larvae was determined from field observations, rearing on trees or on artificial diet, using a modification of Wellington's diet ( 1949).

Number of leaves mined by specific dates were determined by field collections. Cross-sections of mined and unmined leaves were mounted and examined to determine which leaf tissues were destroyed by mining. ${ }^{4}$ Photographs of the cross-sections were made with an Exakta camera mounted on a compound microscope.

Greenhouse trials were conducted during 1965 and 1966 to determine whether photoperiod was a diapause-initiating factor. Approximately 15 early instar larvae were placed on each of 25 potted trees in late August 1965. Five trees each were placed in compartments separated from each other with dark cotton muslin and subjected to photoperiods of 8, 12, 16, 24 hour, or natural daylength in the greenhouse. Natural daylength varied from about 12.7 hours at the beginning to about 10.5 hours at the end of the test. In late July 1966, about 15 first-instar larvae per tree were placed on five trees growing under photoperiods of 12, 13, 14, 15 hours, or a natural daylength of about 13.7 hours at the beginning to about 11 hours at the end of the test. One or two fluorescent and one incandescent bulb were light sources for each treatment. Photoperiods were regulated by electric time-switches. Greenhouse temperature fluctuated from $50^{\circ}$ to $90^{\circ}$ but usually were about $70^{\circ} \mathrm{F}$.

Field collections were used to determine the date and instar at which larvae entered diapause under natural conditions. Approximately 50 leaf mines were examined weekly to determine progress of hibernacula construction by larvae. A hibernaculum is a two-layered, silken bag-like structure in the mined leaves where the larva hibernates (undergoes diapause). Drawings depicting pupal morphology were made with the aid of a camera lucida mounted on a binocular microscope. Mosher (1916) served as a guide in locating and naming the pupal structures.

The pupation site and pupal behavior were studied through field, greenhouse, and growth chamber observations. Length of pupal stage was determined by daily observations of each insect reared on artificial diet in plastic jelly cups. 


\section{Results and Discussion}

\section{Life History}

There is a single generation each year, with about 11 months starting in mid-July spent in the larval stage (Fig. 1). Pupae appear in June. Adults and eggs first appear in July. Larvae enter diapause in late August and September, overwinter in mined shoots, and resume feeding in April. The egg, larva, pupae, and adult are shown in Figures 2-5.

\begin{tabular}{|c|c|c|c|c|c|c|c|}
\hline STAGE & JULY & AUG & SEPT & APRIL & MAY & JUNE & JULY \\
\hline$E G G$ & $E$ & 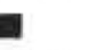 & & & & & \\
\hline LARVA & & & & & & & \\
\hline PUPA & & & & & & E & \\
\hline ADULLT & & & & & & & \\
\hline
\end{tabular}

Figure 1. Seasonal occurrence of the stages of C. houstonana (Grote) in western Kansas. Note break in figure between September and April representing cold months and no development.

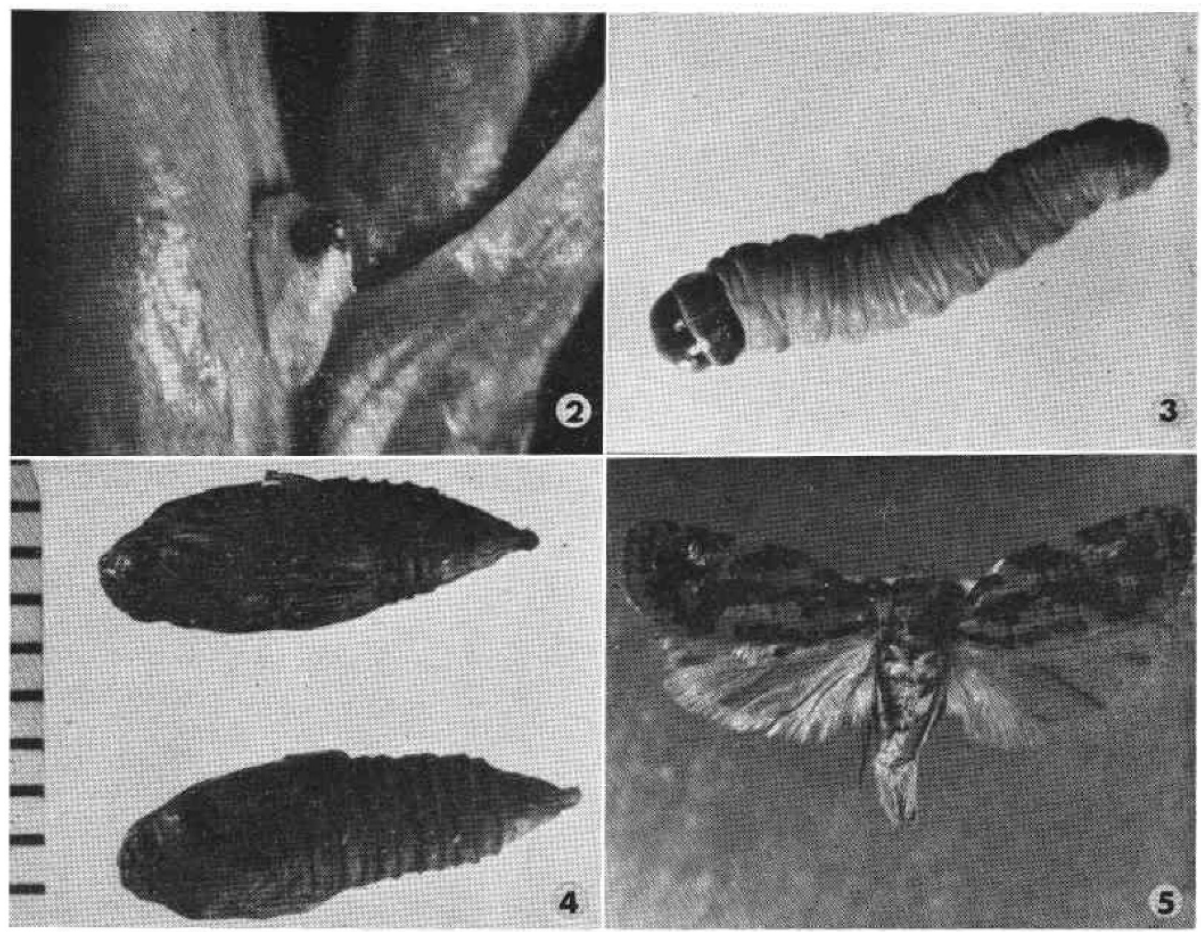

Figures 2-5. Stages of C. houstonana (Grote): (2) egg with fully developed larva; (3) ninth instar larva; (4) (upper) ventral view of male pupa, and (lower) dorsal view of female pupa, each vertical line equals $1 \mathrm{~mm}$; (5) adult, sex undetermined. 


\section{Host Plant Preference}

Food plant preference of Choristoneura houstonana appears to be restricted to conifers. Species of Juniperus are the commonest hosts in Kansas and southeastern Colorado. Juniperus virgini$a n a$, eastern red cedar, is the commonest juniper species and is the commonest host plant for C. houstonana in western Kansas. Juniperus chinensis L. cultivar Pfitzeriana, a low, spreading form, was the sole Juniperus species growing at one site and was heavily infested. When J. virginiana and J. scopulorum Sarg. were growing at the same location, J. virginiana trees were heavily infested; no C. houstonana could be found on J. scopulorum. However, infestations were found on wild J. scopulorum in the lower elevations of the Rocky Mountains in southeastern Colorado, where it appeared to be the only Juniperus available. Light infestations were observed on Chinese arborvitae, Thuja orientalis (L.), growing near infested J. virginiana in a home landscape in Hays, Kansas, but it did not seem to be a preferred host.

\section{Adult}

Less than 24 hours before emerging, the pupa moves with the aid of posterior-pointing spines from the closed end of the silken tube-like shelter to the open end, which usually is toward the basal part of the branch. The pupa is held in the silken shelter by the cremastral setae (Figs. 14 and $16, \mathrm{cs}$ ) that are attached to the silk strands. The head protrudes from the open end of the shelter.

The moths often are difficult to detect while on the host plant, as they are usually immobile and resemble the dead, brownish foliage abundant on trees where larvae have fed. The forewings and body are tan with brown bands and dark margins. The hindwings are grey to whitish with a slightly lighter fringe. A color variation was noticed in 1966. One very dark specimen was collected at one site in Pawnee County while many specimens from a site in Barton County had bright yellow to orange bands on the forewings. Frederic Rindge (personal communication, 1966) states that, in general, Kansas specimens in the American Museum of Natural History collection are darker than those from California, Arizona, Colorado, and Texas.

Adult feeding was not observed in the field or on various sugar solutions in the laboratory.

Adult activity began at dusk and reached a peak a few hours after sunset. Activity lasted through most of the night, tapered off in early morning. On 8 July 1965, a blacklight insect trap was set up at the Larned Country Club to detect flight periods. Very few moths were attracted to blacklight, and most adults were collected between 9:30 P.M. and midnight.

Moths were difficult to find in the daytime because they rested on bark of branches near trunks of trees and were hidden by foliage. When trees were violently shaken, moths would fly from their resting places. At night they flew very little, usually crawled among branches and foliage located near branch tips.

Mating begins at dusk and continues to about 3 A.M. No mating was observed after 3:15 A.M. Pairs in copulo were motionless, usually horizontal in a tail-to-tail position with distal parts of wings overlapping. Most mating pairs collected in plastic jelly cups remained in copulo 3 to 4 hours. One pair, however, remained 12 hours, from 11 P.M. to 11 A.M. Mating pairs did not separate readily when disturbed. 
Oviposition was not observed but apparently occurs some time during the activity period in the night. Eggs are placed in crevices formed at the base where two shoots meet (Fig. 2). When females were caged in jelly cups in the laboratory, eggs were usually deposited on the smooth plastic cap liner. When host plant foliage was placed in the jelly cups, most eggs were deposited on the foliage.

Choristoneura houstonana usually deposits eggs singly. No more than two eggs were ever observed overlapped in the field. However, in jelly cups where space was limited eggs were laid in patches.

Average oviposition period in the laboratory lasted 4.50 days for unmated and 3.36 days for mated females. Unmated females tended to oviposit over a longer period; two oviposited throughout 8 days. Longest oviposition period by a mated female was 6 days.

Oviposition by unmated females began as early as 2 days after they emerged with the most eggs, $26.50 \%$, oviposited on the fourth day. The majority of eggs laid by mated, fertile females, $62.56 \%$, were laid the second day after mating (Table I).

Table I. Oviposition records from day of mating of 11 fertilized C. houstonana females at $80^{\circ} \mathrm{F}$ and $70 \%$ relative humidity

\begin{tabular}{ccccccc}
\hline & \multicolumn{7}{c}{ Days after mating } \\
\cline { 2 - 7 } & 1 & 2 & 3 & 4 & 5 & 6 \\
\hline$\%$ & 8 & 695 & 231 & 138 & 37 & 2 \\
Total & 0.72 & 62.56 & 20.79 & 12.42 & 3.33 & 0.18 \\
Average & & & & & & 1111 \\
\hline
\end{tabular}

\section{Egg}

Eggs are pliable when oviposited, and the shape is governed to some extent by the shape of the substrate on which it is laid. When eggs are deposited on smooth surfaces, such as the cap of a jelly cup or wax paper, they are flat and ovoid with one end of the egg more blunt than the other. The chorion is transparent and is reticulated with a fairly definite pattern. Most "cells" are four-walled and square to rectangular with a few assuming a triangular shape.

The egg is hyaline yellow with the yellow yolk showing through the transparent chorion. No change in egg color can be detected as the embryo develops. When the larva emerges from the egg, it leaves the transparent chorion on the foliage.

Eggs laid by 14 field-collected females in the laboratory averaged $0.628 \mathrm{~mm}$ wide and 0.864 mm long.

The horseshoe-shape of the developing embryo became visible about the fifth day after ovipositing. The dark, embryonic head capsule (Fig. 2) became visible from 6 to 8 days after oviposition, with $75 \%$ visible the seventh day.

The egg incubation period ranged from 8 to 12 days at $80^{\circ} \mathrm{F}$ and $70 \%$ relative humidity with the majority hatching in 10 days.

Larvae emerged from the blunt end of the eggs collected in jelly cups. The emergence hole was just above the area where the egg was attached to the substrate. 
Eleven females laid 1111 eggs (Table I) with 20 broken by activity of the moths in the jelly cups. Average hatch for the remaining 1091 eggs was 77.23\%. Visible embryos were observed in most of the eggs that failed to hatch, indicating fertilization had occurred. Overlapping of the eggs in the jelly cups may have prevented many larvae from emerging.

\section{Larva}

Number of instars and range of head-capsule widths in an instar (Table II) were determined by constructing a head-capsule width-frequency histogram. The histogram indicated eight instars, but there were nine. The widths of the third and fourth instars were similar and fell in the same peak. Each third-instar head capsule was found in the hibernaculum when the fourthinstar larva was present. The average width of third- and fourth-instar head capsules was 0.352 and $0.355 \mathrm{~mm}$, respectively. Lack of growth between the two may result as the larvae did not feed in the late third instar and used energy constructing a hibernaculum. When diapause did not occur as in the greenhouse and growth chamber experiments, growth occurred between the third and fourth instars (Table III).

Table II. Head capsule widths (in $\mathrm{mm}$ ) of larval instars of C. houstonana as determined by field collections and calculated using Dyar's Law

\begin{tabular}{ccccc}
\hline & \multicolumn{3}{c}{ Range } & \\
Instar & Minimum & Maximum & Peak & Dyar's \\
\cline { 2 - 4 } I & 0.19 & 0.25 & 0.23 & 0.23 \\
II & 0.25 & 0.30 & 0.27 & 0.31 \\
III & 0.30 & 0.46 & 0.38 & 0.43 \\
IV & 0.30 & 0.46 & 0.38 & $*$ \\
V & 0.46 & 0.65 & 0.57 & 0.59 \\
VI & 0.65 & 0.84 & 0.72 & 0.81 \\
VII & 0.84 & 1.29 & 1.06 & 1.11 \\
VIII & 1.29 & 1.86 & 1.52 & $1.52^{+}$ \\
IX & 1.86 & 2.43 & 2.09 & $2.09^{+}$ \\
\hline
\end{tabular}

*This instar unaccounted for in Dyar's method.

†Two measured head-capsule widths used as base for calculations.

Rearing larvae in plastic boxes, placed around seedling branches, resulted in 8 to 11 instars (Table III), with no difference between sexes. All larvae undergoing either 10 or 11 instars were reared on juniper seedlings in the greenhouse. Average days in the larval stage were more for those reared in the greenhouse than for those reared in a growth chamber. Plastic boxes in the greenhouse, with very small ventilation holes and little circulation, resulted in condensation and mold growth. Lower temperatures and mold growth may have produced sufficient stress to cause the larvae to pass through more instars. Larvae reared on juniper foliage in the growth chamber passed through eight or nine instars. 
Table III. Number of instars and width of head capsules (in $\mathrm{mm}$ ) of larvae enclosed in plastic boxes and reared on trees in a growth chamber or greenhouse under 17-hour photoperiods

\begin{tabular}{|c|c|c|c|c|c|c|c|c|c|c|c|c|}
\hline \multirow{2}{*}{$\begin{array}{l}\text { No. of } \\
\text { instars }\end{array}$} & \multirow[b]{2}{*}{ Sex } & \multicolumn{11}{|c|}{ Instar } \\
\hline & & I & II & III & IV & V & VI & VII & VIII & IX & $X$ & XI \\
\hline 9 & Male* & 0.23 & 0.27 & 0.34 & 0.46 & 0.65 & 0.84 & 1.10 & 1.48 & $\mathrm{~B}^{+}$ & & \\
\hline 9 & Male* & 0.23 & 0.25 & 0.37 & 0.57 & 0.72 & 1.03 & 1.33 & 1.79 & B & & \\
\hline 11 & Male* & 0.23 & 0.27 & 0.30 & 0.34 & 0.42 & 0.61 & 0.84 & 1.03 & 1.37 & 1.67 & B \\
\hline 8 & Male* & 0.21 & 0.30 & 0.34 & 0.42 & 0.53 & 0.76 & 1.44 & B & & & \\
\hline 8 & Male* & 0.23 & 0.30 & 0.46 & 0.68 & 0.95 & 1.33 & 1.56 & B & & & \\
\hline 8 & Male & 0.23 & 0.27 & 0.30 & 0.46 & 0.65 & 0.91 & 1.37 & B & & & \\
\hline 8 & Male & 0.23 & 0.30 & 0.38 & 0.46 & 0.72 & 0.91 & 1.14 & B & & & \\
\hline 10 & Female ${ }^{*}$ & 0.23 & 0.27 & 0.42 & 0.53 & 0.80 & 1.06 & 1.18 & 1.44 & 1.79 & B & \\
\hline 9 & Female ${ }^{*}$ & 0.23 & 0.27 & 0.38 & 0.46 & 0.57 & 0.76 & 1.03 & 1.52 & B & & \\
\hline 11 & Female $^{*}$ & 0.23 & 0.27 & 0.34 & 0.40 & 0.46 & 0.61 & 0.87 & 1.14 & 1.52 & 1.90 & B \\
\hline 8 & Female & 0.23 & 0.27 & 0.34 & 0.49 & 0.76 & 1.14 & 1.67 & B & & & \\
\hline
\end{tabular}

*Reared in greenhouse.

tHead capsule split during pupation but approximate size determined.

The use of Dyar's method (Dyar 1890) to determine the number of instars indicated eight (Table II). His method fairly accurately indicated the number of instars but, of course, did not account for lack of geometrical progression between third and fourth instars in the field.

The number of instars in the field apparently is usually nine; however, the number may vary slightly due to nutritional and(or) environmental factors.

On hatching, the first instar searches for a suitable feeding site, usually near the hatched egg at the base of two joining juniper shoots. The larva begins by spinning silk between the two shoots, and within about 8 hours begins to chew an entrance hole through the epidermis. Entrance holes averaged $0.58 \mathrm{~mm}$ long and $0.34 \mathrm{~mm}$ wide. Also used through the leaf-mining period, the entrance hole is increased by later instars.

Larvae mining leaves avoid resinous areas (Figs. 8-10). External portions of these areas are visible as light-colored oval spots on the leaf epidermis. McGugan (1954) reported that spruce budworms (C. fumiferana (Clem.)) avoid resin ducts of pine needles when mining. The epidermis and usually the hypodermis in the portion of the leaf distal to the shoot axis remain (Fig. 9) while the inner portion, the parenchyma and vascular tissue, are eaten. The uneaten epidermis and the hypodermis of several leaves of a shoot shelter the larva. A larva mines from the entrance hole toward the shoot tip (Fig. 6) but never down toward the shoot base. Arranging the mine above the entrance hole may facilitate removal of fecal pellets and frass from the mine by gravity. The larval mines usually are free of fecal pellets and frass. Larvae are solitary; more than one has not been observed in a mine. As it develops, each larva mines more than one leaf, from first instar in July to the overwintering fourth-instar larva in September. Average leaves mined increased from 4.815 July 1965 by mostly first-instar larvae to 32.417 September 1965, when mining ceased for the season (Table IV). Many leaves not mined died because the vascular elements in the shoot axis were eaten. 


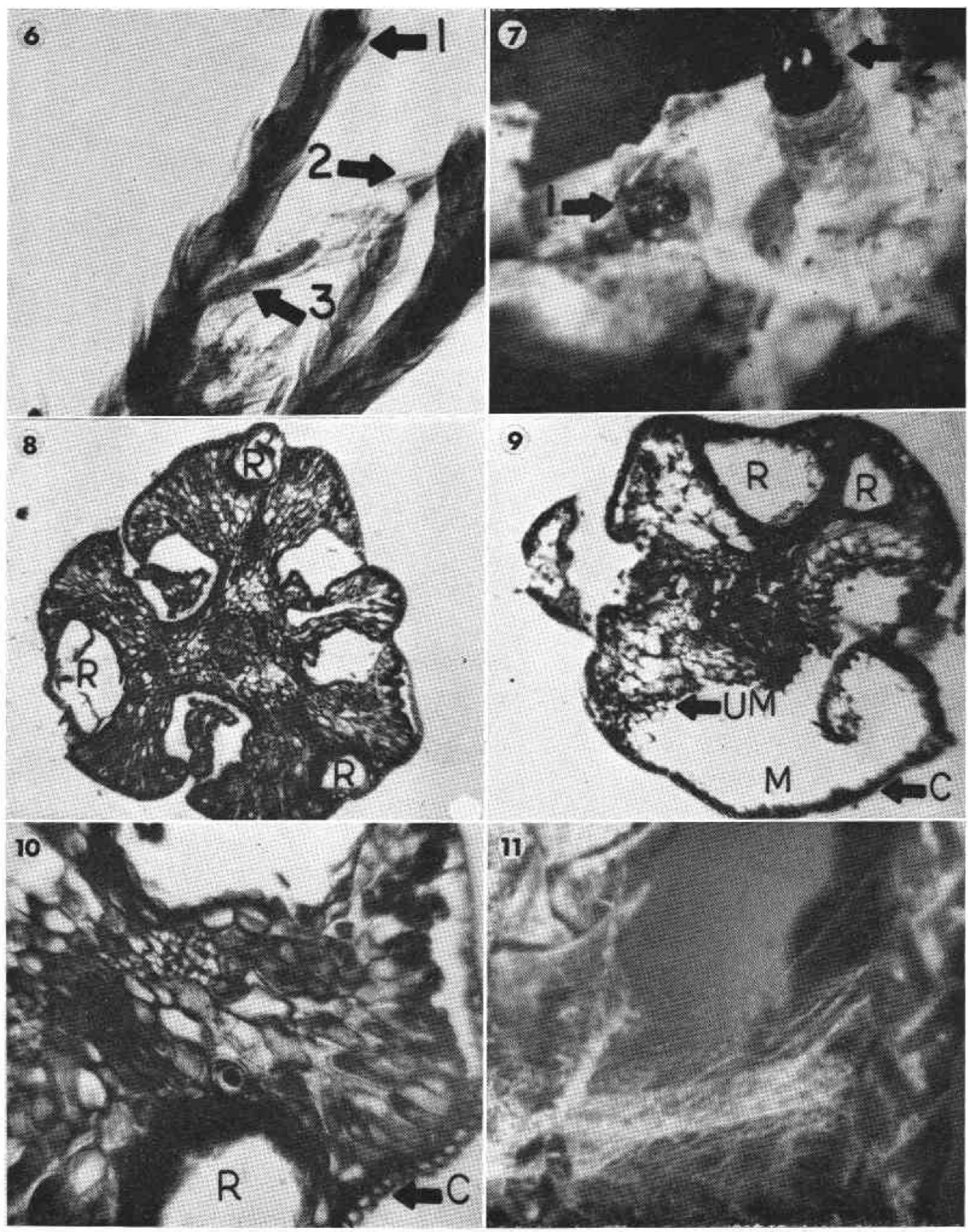

Caption next page 
Figures 6-11. (6) radiograph of an overwintering larva in a hibernaculum in a mined shoot. Arrow 1 points to the tip of an unmined shoot; (2) to a mined shoot tip; and (3) to the larva with its head to the left, downward. The entrance to the mine is just below the anterior portion of the larva, with frass and fecal pellets around the entrance. (7) fourth-instar larva (2) and the loose head capsule of the third instar (1), both in a dissected hibernaculum. The portion of the hibernaculum that separates the loose head capsule from the larva is a ridge-like mass of silk, just right of the third-instar head capsule. (8) cross-section of an unmined J. virginiana shoot showing resinous areas of three leaves $(R)$ and tips of three other leaves. (9) cross-section of a J. virginiana shoot with lower leaf partially mined. Photograph illustrates mined (M) and unmined (UM) portions of leaf. The epidermal and some hypodermal cells (C) are visible in the lower right portion of the photograph. The resinous (R) areas of two leaves are in the upper portion of the photograph. (10) view of more highly magnified portion of a leaf showing resinous (R) area and epidermal cells (C). (11) middle-instar larva in act of webbing two shoots together. Head is at the left. The white area at the lower left is leaf sap in the webbing.

\begin{tabular}{lccc}
\hline \multicolumn{2}{c}{ Table IV. Number of leaves mined by indicated dates, 1965-1966 } \\
\hline & & \multicolumn{2}{c}{ Av. no. mined } \\
\cline { 3 - 4 } Date & No. examined & Summer & Spring \\
\hline 15 July 1965 & 9 & 4.8 & \\
20 July 1965 & 11 & 5.8 & \\
27 July 1965 & 20 & 7.4 & \\
12 Aug. 1965 & 57 & 8.0 & \\
27 Aug. 1965 & 44 & 15.3 & 7.0 \\
17 Sept. 1965 & 27 & 32.4 & 13.4 \\
26 Apr. 1966 & 2 & & \\
2 May 1966 & 10 & & \\
16 May 1966 & 10 & & \\
\hline
\end{tabular}

By 15 April 1966, 9\% of the larvae had resumed feeding in mines and by 9 May 1966, all were feeding in mines or externally near mine entrances.

Larvae were mostly in the fourth instar by 26 April 1966, 87\% were mining and $13 \%$ had begun feeding externally on leaves (Table V). By 16 May 1966, 13.4 additional leaves per larva had been mined since spring feeding began (Table IV). That was the last date mining was observed (Table V). Fifth instars were the last to mine, and some fifth instars began feeding externally.

Table V. Percentage of larvae feeding in mines and externally at indicated dates, 1966

\begin{tabular}{lccc}
\hline & & \multicolumn{2}{c}{ Feeding habit } \\
\cline { 3 - 4 } Date & Instar & Mines & External \\
\hline 26 Apr. & 4,5 & 87 & 13 \\
2 May & 4,5 & 82 & 18 \\
9 May & 5,6 & 78 & 22 \\
16 May & $5,6,7$ & 38 & 62 \\
26 May & 6,7 & 0 & 100 \\
\hline
\end{tabular}


Webbing of shoots in late spring and summer (Figs. 11, 12) is partially responsible for the ugliness of highly infested trees. The silk spun between shoots apparently contracts as it dries, pulls the shoots together, and causes branches to appear matted. Average number of shoots webbed together by the time a larvae had pupated was 18.33. Larvae spin silken tunnels in the webbed-together foliage (Fig. 12). Feeding by later instars usually is on the part of the branch just outside the tunnel. The silken web at the opening of the tunnel is often funnel-like. The larvae leave the tunnel, remove entire leaves or shoots from the branches and carry them back to the tunnel, and feed. Some leaves were damaged very little when eaten; the form of a leaf was still distinct in a fecal pellet.

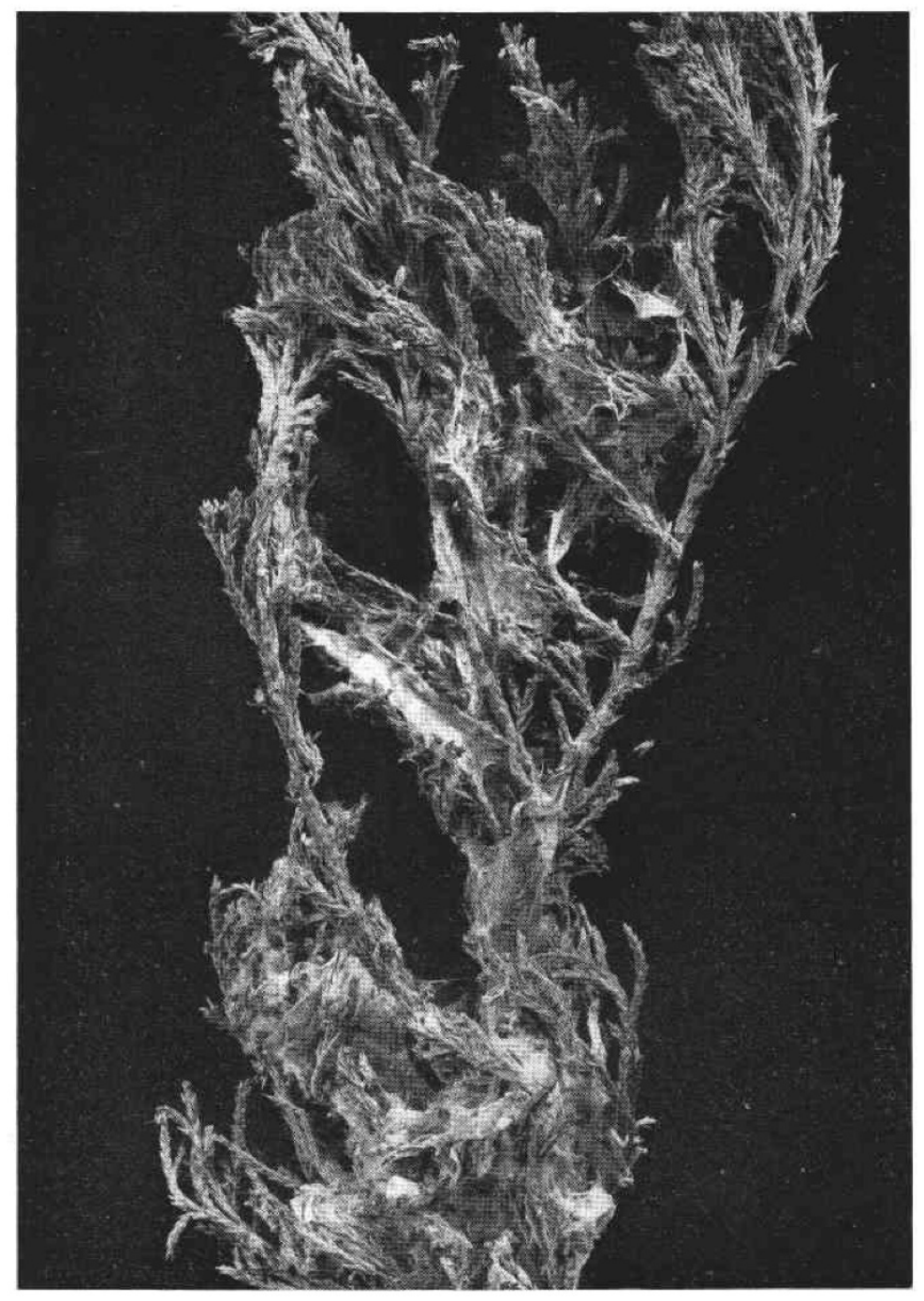

Figure 12. A severely infested branch of J. virginiana. One branch has been removed, exposing silken tunnel-like shelters spun by late-instar larvae. 
When food became scarce, as it did on heavily infested trees in the diapause experiments in the greenhouse, some larvae left the foliage and were found at the base of the trees, while others appeared to have starved on the trees.

Investigations to determine the date at which larvae enter diapause and the effect of photoperiod in initiating diapause were conducted through field collections and greenhouse experiments. It was not determined in which stage the process leading to diapause was initiated. Hibernaculum construction, however, was started by third-instar larvae in the field. The hibernaculum, a two-layered silken bag, is usually located near the entrance hole and a portion usually plugs the entrance hole. The entrance hole is always covered with silk during diapause. The first layer of the hibernaculum apparently is spun by the third instar. After the third instar molts in the bag, the loose third-instar head capsule is pushed to one end of the bag and another layer is spun, excluding the third-instar head capsule from the fourth-instar larva (Fig. 7). Third-instar head capsules were found in $75 \%$ of the field collected hibernacula checked. The head of the overwintering fourth-instar larva was always toward the base of the shoot and usually at the base of the shoot as shown in the radiograph (Fig. 6).

Radiographs were used to determine the presence or absence of larvae in mines. On the best radiographs, legs and head capsules could be detected. To measure the accuracy in locating larvae in mines, radiographs were first examined against a bright light followed by a dissecting of the x-rayed shoot. Accuracy of $81.1 \%$ in determining the presence of larvae was achieved. Some larvae were not visible on the radiograph because they were beneath several crossing shoots. However, other objects were not mistaken for larvae.

Larvae were in either a folded position or stretched out in the overwintering mine.

Hibernaculum construction at Larned began by 27 August 1965. By 30 September 1965, 98\% were in hibernacula (Table VI). All live larvae examined 26 February 1966 were in hibernacula. Some dead larvae were in hibernacula, others were in mined shoots in which no hibernaculum had been constructed. Most mines examined during diapause were occupied by live larvae, indicating that overwintering, in most cases, occurred in the same mine where feeding began.

\begin{tabular}{cc}
\hline Table VI. Percentage of larvae in hibernacula at indicated dates, 1965-1966 \\
\hline Date & $\%$ \\
\hline 27 Aug. 1965 & 4 \\
13 Sept. 1965 & 67 \\
17 Sept. 1965 & 69 \\
30 Sept. 1965 & 98 \\
26 Feb. $1966^{*}$ & 100 \\
\hline
\end{tabular}

*The $100 \%$ level likely was reached shortly after 30 September.

Greenhouse experiments to determine the effect of photoperiod on diapause in 1965 indicated that exposure to photoperiods of 16 or 24 hours prevented diapause. Second and third instars were placed on trees between 20 August and 1 September 1965 and subjected to photoperiods of $8,12,16$, and 24 hours and natural daylength (about 12.7 hours at the beginning and 10.5 hours at the end). On 24 October, feeding was observed only under the 16- and 24-hour 
photoperiods with adults emerging 23 November. Larvae exposed to 8 and 12 hours and natural daylength photoperiods were in hibernacula and died there, without pupating. In 1966, first-instar larvae were placed on trees and allowed to grow under photoperiods of 12, 13, 14, and 15 hours and natural daylength of about 13.7 hours at the beginning and about 11 hours at the end of the test. Larvae exposed to 12 and 13 hours and natural daylength diapaused after feeding for about 1 month, while those exposed to 14 and 15 hours continued feeding and emerged as adults in October and November. Thus, a photoperiod between 13 and 14 hours initiated diapause in the greenhouse experiments.

Two overwintering larvae each placed in a plastic box on trees as first instars and exposed to natural daylength in the greenhouse for about 2 months were examined in November. Four head capsules, including one on each live larva, were found in each box. They indicated that larvae under those conditions, like those collected in the field, will overwinter in the fourth instar.

Pupation occurs in the silk tunnel constructed by the larva. Prior to pupation, the last instar spins a great amount of silk with strands very close together in the shelter. The silk forms a loose-fitting cocoon. The shelter is closed at the end farthest from the branch base. The opposite end of the shelter is left open for adult emergence.

\section{Pupa}

Pupae were collected in the field as well as reared from larvae in the laboratory. In the field, pupation begins in late June (Fig. 1), and some pupae were found in the field through most of July.

The pupa (Figs. 4, 13-16) is obtect with limbs visible externally but adhering to the body's surface. The pupa is first greenish, turns light brown, and then dark brown. Spines are present on the dorsum of most abdominal segments. They apparently aid the pupa in moving to the shelter opening just before the adult emerges. Sexes can be distinguished readily by examining the genital opening, which consists of two slits almost joined on the female and two protuberances with a single slit between them on the male (Figs. 14, 16). In addition, abdominal segments 7 and 8 are completely separated by a suture ventrally in the male but not in the female. The cremaster (er) has six setae (cs), which serve as hooks for attaching the pupa to the pupation shelter. The posterior end of the pupa is held in the shelter by the setae when it protrudes from the shelter for adult emergence. The empty pupal cases are often found attached to the shelter 1 year after the adult has emerged. 

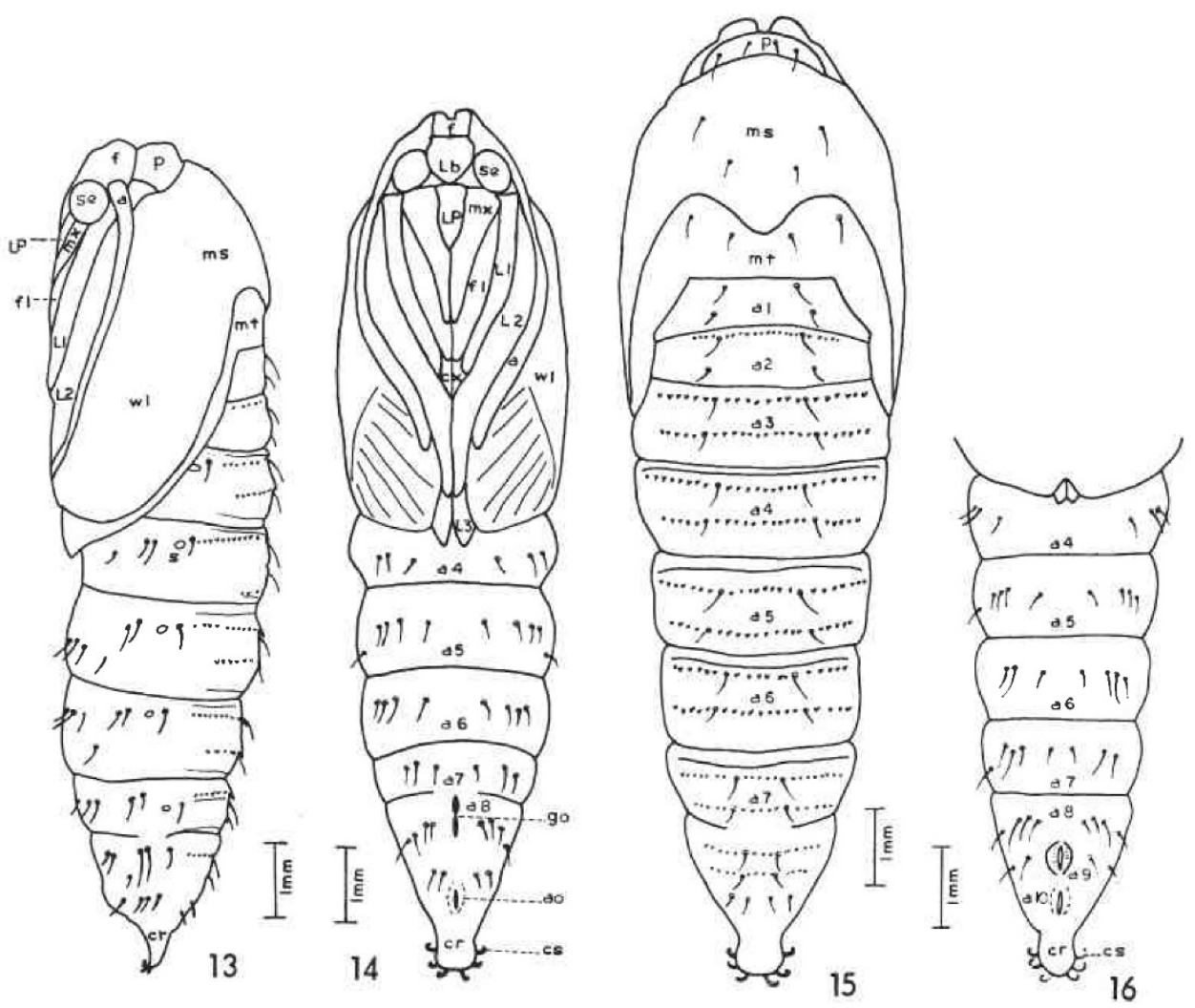

Figures 13-16. External pupal morphology: (13) lateral view of female; (14) ventral view of female; (15) dorsal view of female; (16) ventral view of male. a, antenna; al-a10, abdominal segments 1-10; ao, anal opening; cr, cremaster; cs, cremastral setae; cx, coxa of mesothoracic leg; f, front; f1, femur of prothoracic leg; go, genital opening; L1, prothoracic leg; L2, mesothoracic leg; L3, metathoracic leg; Lb, labrum; LP, labial palpi, ms, mesothorax; mt, metathorax; $\mathrm{mx}$, maxilla; $\mathrm{p}$, prothorax; s, spiracle; se, sculptured eye piece; $\mathrm{w} 1$, mesothoracic wing.

Length of male and female pupae varies little: average of 46 field-collected males was 10.50 $\mathrm{mm}$ and 45 females, $11.03 \mathrm{~mm}$; averages on artificial diets were slightly greater, $10.93 \mathrm{~mm}$ for 38 males and $11.59 \mathrm{~mm}$ for 45 females.

Just before the larva pupated, the prothorax was greatly compressed longitudinally. A larva usually pupated the day after the prothorax was first observed as compressed. Days in pupal stage were similar for both sexes, 9.91 and 9.94 days, for males and females, respectively (in a rearing room at $80^{\circ} \mathrm{F}$ ). The length of pupal stage in the field was not determined. 


\section{Notes}

1. Contribution No. 947. Funds provided in part by McIntyre-Stennis Project 671.

A portion of a dissertation presented as partial fulfillment of the requirements for the degree Doctor of Philosophy at Kansas State University.

2. No. 6916, Premium Plastics Co., 2440 S. Indiana Ave., Chicago, Illinois.

3. Althor Products, 2260 Benson Ave., Brooklyn, New York.

4. Juniper foliage sectioned, stained, and mounted by Walter Schaffer, graduate technical assistant, Department of Plant Pathology, Kansas State University.

\section{References}

Dyar, H. G. 1890. The number of molts of lepidopterous larvae. Psyche 5: 420-422.

Freeman, T. N. 1958. The Archipinae of North America (Lepidoptera: Tortricidae). Can. Ent. Suppl. 7.

Grote, A. R. 1873. Description of new North American moths. Bull. Buffalo Soc. nat. Hist. 1: 15-16.

Heinrichs, E. A. 1967. Distribution of the eggs and leaf mines of Choristoneura houstonana (Grote) (Lepidoptera: Tortricidae) attacking eastern redcedar, Juniperus virginiana. J. Kans. Ent. Soc. 40: 353-355.

Heinrichs, E. A., and H. E. Thompson. 1968. Parasites, predators, and other arthropods associated with Choristoneura houstonana (Lepidoptera: Tortricidae) on Juniperus species in Kansas. Can. Ent. 100: $33-39$.

McGugan, B. M. 1954. Needle mining habits and larval instars of the spruce budworm. Can. Ent. 86: 439-454.

Mosher, Edna. 1916. A classification of Lepidoptera based on characteristics of the pupa. Bull. Ill. St. Lab. Nat. Hist. 12: 17-159.

Powell, J. A. 1962. Host parasite relationships of California Tortricinae (Lepidoptera: Tortricidae). PanPacif. Ent. 35: 109-114.

Powell, J. A. 1964. Biological and taxonomic studies on Tortricine moths, with special reference to the species in California. Univ. Calif. Publs. Ent. V: 32.

Wellington, E. F. 1949. Artificial media for rearing some phytophagous Lepidoptera. Nature, Lond. 163: 574. 